See discussions, stats, and author profiles for this publication at: https://www.researchgate.net/publication/325848994

\title{
A contribution to the identification of charcoal origin in Brazil III: Microscopic identification of 10 Cerrado species
}

Article in Australian Journal of Botany · January 2018

DOI: $10.1071 /$ BT17196

\section{CITATION}

6 authors, including:

Julia Sonsin

University of Brasília

8 PUBLICATIONS 63 CITATIONS

SEE PROFILE

Carmen Regina Marcati

São Paulo State University

39 PUBLICATIONS 462 CITATIONS

SEE PROFILE
READS

55

Silvana Nisgoski

Universidade Federal do Paraná

102 PUBLICATIONS 330 CITATIONS

SEE PROFILE

Adriano Ballarin

São Paulo State University

61 PUBLICATIONS 373 CITATIONS

SEE PROFILE

Some of the authors of this publication are also working on these related projects:

Project Wood anatomy of cerrado species View project

Project Guapuruvu View project 


\title{
A contribution to the identification of charcoal origin in Brazil III: microscopic identification of 10 Cerrado species
}

\author{
Thaís A. P. Gonçalves ${ }^{\mathrm{A}, \mathrm{F}}$, Julia Sonsin-Oliveira ${ }^{\mathrm{B}}$, Silvana Nisgoski ${ }^{\mathrm{C}}$, Carmen R. Marcati ${ }^{\mathrm{D}}$, \\ Adriano W. Ballarin ${ }^{\mathrm{E}}$ and Graciela I. B. Muñiz ${ }^{\mathrm{C}}$ \\ AMuseu Paraense Emílio Goeldi, Coordenação de Botânica, Avenida Perimetral, 1901, Terra Firme, \\ Belém, PA, 66077-830, Brazil. \\ ${ }^{B}$ Universidade de Brasilia - UNB, Campus Universitário Darcy Ribeiro, Inst. Ciências Biológicas, \\ Asa Norte, Brasília, DF, 70910-900, Brazil. \\ CUniversidade Federal do Paraná, Departamento de Engenharia e Tecnologia Florestal, Avenida Prefeito \\ Lothário Meissner, 632, Jardim Botânico, Curitiba, PR, 80210-170, Brazil. \\ DUNESP, Departamento de Recursos Naturais, Faculdade de Ciências Agronômicas, Campus de Botucatu, \\ SP, CP237, CEP18603-970, Brazil. \\ EUNESP, Departamento de Engenharia Rural, Campus de Botucatu, SP, CP237, CEP18603-970, Brazil. \\ FCorresponding author. Email: th_goncalves@yahoo.com.br
}

\begin{abstract}
Brazil has one of the richest biodiversities in the world. The Brazilian savanna is a hotspot for conservation priorities and its deforestation is of global concern. Conservation in this biome is threatened by unsustainable use of forests, such as illegal logging for charcoal production. Thus, government agents need to verify whether charcoal loads follow the Document of Forestry Origin (DOF). To improve charcoal identification, our study presents the microscopic description of 10 Cerrado species and provides an identification key to aid government agents during surveillance. We analysed charcoal samples with a scanning electron microscope. The method of carbonisation simulated real conditions. We chose species with similar wood anatomy (sparse axial parenchyma and narrow rays), which increases misidentification by forest controllers because of their difficulty to identify these features. Also, paratracheal scanty, diffuse and diffuse-inaggregates parenchyma were harder to recognise in charcoal than in wood. Other features, such as vessels, rays and abundant axial parenchyma, were easily identified. The present work can be used as a part of a charcoal anatomy database focussed on preventing deforestation in Brazil and in other countries with similar problems.
\end{abstract}

Additional keywords: anatomy, forestry supervision, Nature Conservancy.

Received 13 October 2017, accepted 4 May 2018, published online 19 June 2018

\section{Introduction}

It is difficult to control charcoal production and distribution in Brazil. Governmental surveillance activities are performed on the basis of rules in the Document of Forestry Origin (DOF) and the Federal Law no. 12.651, known as 'New Forestry Code' (Ganem 2013). These documents are designed to guarantee sustainable production of charcoal from planted or native species, with a forest management plan produced as part of the environmental licensing process. One of the responsibilities of government agents is to verify the compliance between the load and DOF of the charcoal. However, this is a difficult task because an accurate identification demands specialist skills in wood anatomy (Davrieux et al. 2010). Few courses focus on wood and charcoal identification. Furthermore, there are few works on the subject to provide a good database for practical applications.
This situation becomes even more critical considering the continental size of Brazil ( 8.5 million $\mathrm{km}^{2}$ ) and the presence of six biomes, Amazon, Cerrado, Caatinga, Atlantic Forest, Pantanal and Pampa (SFB 2010; IBGE 2012). Approximately 8000 species of trees are known in Brazil (reflora.jbrj.gov.br, accessed 10 August 2017); taking into account the published studies on wood anatomy of Brazilian species (e.g. Wheeler 2011), it is necessary to develop new studies.

Charcoal anatomy or anthracology is possible because features of wood anatomy are usually well preserved in charcoal (e.g. Prior and Gasson 1993; Gonçalves et al. 2012). This science has developed worldwide, with special application in archaeological and paleoenvironmental contexts (e.g. Vernet 1972; Prior and Williams 1985; Marguerie 1992; Heinz and Thiébault 1998; Figueiral and Mosbrugger 2000; Asouti 2003; 
Scheel-Ybert et al. 2003; Théry-Parisot et al. 2010; Byrne et al. 2013; Dotte-Sarout et al. 2015).

The deforestation of protected areas to produce charcoal is a well known global problem (see Nellemann et al. 2014). Therefore, recently in Brazil, works involving characterisation of charcoal anatomy have been directed to forestry supervisors (Gonçalves et al. 2008, 2011, 2012, 2014, 2016; Gonçalves and Scheel-Ybert 2012, 2016; Muñiz et al. 2012a, 2012b, 2013, 2016; Nisgoski et al. 2012, 2014, 2015; Scheel-Ybert and Gonçalves 2017). This initiative has also begun in Mozambique as the Miombo' forest (savanna ecoregions) is highly threatened by irregular and unsustainable charcoal production (Afonso et al. 2015).

The process of any identification is to compare the DOF (MMA 2011) and the wood or charcoals. First, macroscopic analysis is conducted on charcoal samples (Gonçalves et al. 2016), which allows the immediate evaluation of species declared in the DOF, verifying whether the load is regular or irregular. Often, loads of charcoal that are said to be from eucalypt reforestation and are supposed to be homogenous are in fact composed of a mixture of native species and are, consequently, illegal. When a more detailed investigation is necessary to identify the charcoals, microscopic analysis is required.

The Cerrado (Brazilian savanna) originally covered nearly 2 million $\mathrm{km}^{2}$ in Brazil (IBGE 2004). It is considered a biodiversity hotspot (Myers et al. 2000), and has been suffering high rates of deforestation and land-use change. For instance, between 1990 and 2010, the Cerrado lost $265595 \mathrm{~km}^{2}$ of natural vegetation (Beuchle et al. 2015). The main causes of this deforestation are land conversion to agriculture and cattle grazing (e.g. Klink and Machado 2005). Charcoal consumption, by itself, represents the deforestation of $\sim 16000 \mathrm{~km}^{2}$ of the Cerrado (MMA 2011).

In the present study, the charcoal anatomy of 10 species from the Cerrado is characterised microscopically. We also provide an identification key to these species. It is justified by the illegal commerce of charcoal and the need for conservancy of the Cerrado. Our main goal is to provide scientific information to the forestry supervisors in Brazil and other countries with similar issues.

\section{Materials and methods}

Wood samples from 10 species were collected from a 180-ha private reserve of Cerrado sensu lato 'Fazenda Palmeira da Serra' in São Paulo State, Brazil ( $\left.23^{\circ} 02^{\prime} 55.5^{\prime \prime} \mathrm{S}, 48^{\circ} 31^{\prime} 26.1^{\prime \prime} \mathrm{W}\right)$.

We selected the species on the basis of the failure risk of forest controllers in identifying samples, owing to its wood anatomy (Table 1).

The wood samples were wrapped in tinfoil, submitted to a carbonisation process in a muffle furnace (Q318S, Quimis, São Paulo, Brazil) for $\sim 5 \mathrm{~h}$, using a heating rate of $1.66^{\circ} \mathrm{C} \mathrm{min}^{-1}$ and

Table 1. List of species analysed

The geographic distribution is according Flora do Brasil (reflora.jbrj.gov.br, accessed 10 August 2017).

\begin{tabular}{|c|c|c|}
\hline Species & Family & Geographic distribution (states) \\
\hline Lithraea molleoides (Vell.) Engl. & Anacardiaceae R.Br. & $\begin{array}{l}\text { North-east (Bahia, Paraíba, Pernambuco, Rio Grande do Norte, Sergipe); central- } \\
\text { west (Distrito Federal, Goiás, Mato Grosso do Sul, Mato Grosso); south-east } \\
\text { (Espírito Santo, Minas Gerais, Rio de Janeiro, São Paulo); south (Paraná, Rio } \\
\text { Grande do Sul, Santa Catarina) }\end{array}$ \\
\hline $\begin{array}{l}\text { Tabebuia aurea (Silva Manso) Benth. } \\
\text { \& Hook. f.ex S.Moore }\end{array}$ & Bignoniaceae Juss. & $\begin{array}{l}\text { North (Amazonas, Amapá, Pará, Tocantins); north-east (Alagoas, Bahia, Ceará, } \\
\text { Maranhão, Paraíba, Pernambuco, Piauí, Rio Grande do Norte, Sergipe); } \\
\text { central-west (Distrito Federal, Goiás, Mato Grosso do Sul, Mato Grosso); } \\
\text { south-east (Minas Gerais, São Paulo); south (Paraná) }\end{array}$ \\
\hline Terminalia glabrescens Mart. & Combretaceae R.Br. & $\begin{array}{l}\text { North (Tocantins); north-east (Alagoas, Bahia, Ceará, Maranhão, Piauí); central- } \\
\text { west (Distrito Federal, Goiás, Mato Grosso do Sul, Mato Grosso); south-east } \\
\text { (Espírito Santo, Minas Gerais, Rio de Janeiro, São Paulo); south (Paraná) }\end{array}$ \\
\hline Ocotea corymbosa (Meisn.) Mez & Lauraceae Juss. & $\begin{array}{l}\text { North (Tocantins); north-east (Bahia); central-west (Distrito Federal, Goiás, } \\
\text { Mato Grosso do Sul); south-east (Espírito Santo, Minas Gerais, Rio de Janeiro, } \\
\text { São Paulo); south (Paraná, Rio Grande do Sul, Santa Catarina) }\end{array}$ \\
\hline $\begin{array}{l}\text { Pleroma oleifolium R.Romero \& } \\
\text { Versiane }\end{array}$ & Melastomataceae A.Juss. & South-east (Espírito Santo, Minas Gerais, São Paulo); south (Paraná) \\
\hline Myrcia bella Cambess. & Myrtaceae Juss. & $\begin{array}{l}\text { North (Tocantins); north-east (Bahia); central-west (Goiás, Mato Grosso do Sul, } \\
\text { Mato Grosso); south-east (Minas Gerais, São Paulo) }\end{array}$ \\
\hline $\begin{array}{l}\text { Tocoyena formosa (Cham. \& Schltdl.) } \\
\text { K.Schum. }\end{array}$ & Rubiaceae Juss. & $\begin{array}{l}\text { North (Amazonas, Amapá, Pará, Rondônia, Tocantins); north-east (Alagoas, } \\
\text { Bahia, Ceará, Maranhão, Paraíba, Pernambuco, Piauí, Rio Grande do Norte, } \\
\text { Sergipe); central-west (Distrito Federal, Goiás, Mato Grosso do Sul, Mato } \\
\text { Grosso); south-east (Espírito Santo, Minas Gerais, Rio de Janeiro, São Paulo); } \\
\text { south (Paraná) }\end{array}$ \\
\hline $\begin{array}{l}\text { Siparuna brasiliensis (Spreng.) } \\
\text { A.DC. }\end{array}$ & $\begin{array}{l}\text { Siparunaceae (A.DC.) } \\
\text { Schodde }\end{array}$ & $\begin{array}{l}\text { North-east (Bahia); central-west (Distrito Federal, Goiás); south-east (Espírito } \\
\text { Santo, Minas Gerais, Rio de Janeiro, São Paulo) }\end{array}$ \\
\hline Styrax ferrugineus Nees \& Mart. & $\begin{array}{l}\text { Styracaceae DC. \& } \\
\text { Spreng. }\end{array}$ & $\begin{array}{l}\text { North (Rondônia); central-west (Distrito Federal, Goiás, Mato Grosso do Sul, } \\
\text { Mato Grosso); south-east (Espírito Santo, Minas Gerais, Rio de Janeiro, São } \\
\text { Paulo); south (Paraná) }\end{array}$ \\
\hline $\begin{array}{l}\text { Symplocos pubescens Klotzsch ex } \\
\text { Benth. }\end{array}$ & Symplocaceae Desf. & $\begin{array}{l}\text { Central-west (Distrito Federal, Goiás, Mato Grosso do Sul, Mato Grosso); } \\
\text { south-east (Minas Gerais, Rio de Janeiro, São Paulo); South (Paraná) }\end{array}$ \\
\hline
\end{tabular}


reaching a final temperature of $450^{\circ} \mathrm{C}$, which was maintained for two additional hours (Muñiz et al. 2012b).

The resulting charcoal samples were manually broken and analysed with the aid of a scanning electron microscope (SEM) without sputter-coating the specimens with gold or platinum.

The charcoal samples were deposited at the charcoal collection of 'Laboratório de Anatomia e Qualidade da Madeira' of Universidade Federal do Paraná (LANAQM/ UFPR) in Curitiba, Paraná State, Brazil. We used the IAWA Committee (1989) list as a basis for descriptions. We considered 'short confluent' when axial parenchyma cells involved up to four vessels and 'long confluent' for more than five vessels; this terminology was used to help the identification of the species in the field.

A dichotomous key was developed on the basis of qualitative and quantitative data, to facilitate the charcoal identification by government agents during surveillance. To use this key, the agents need to compare whether the anatomical feature is present or absent. The 'and/or' means that the features can be present together or just one of them.

\section{Results}

The anatomical descriptions of the charcoal are given. We present the quantitative results as 'mean values (minimummaximum), standard deviation'. A dichotomous key follows the descriptions.

\section{Lithraea molleoides (Fig. 1a-c)}

Growth rings: boundaries distinct, demarcated by thick-walled and radially flattened fibres. Vessels: diffuse-porous; solitary and in short (1-3 cells) radial multiples; tangential diameter 48(35-67)9 $\mu \mathrm{m}$; 67(55-81)8 vessels per square millimetre; simple perforation plates; alternate intervessel pits. Axial parenchyma: scanty paratracheal and vasicentric. Rays: 1-3seriate; 10(6-14)2 rays per linear millimetre; body ray cells procumbent with one row of upright and/or square marginal cells. Fibres: very thick-walled; septate. Storied structure: absent. Secretory elements: absent. Mineral inclusions: prismatic crystals in chambered axial parenchyma and rare in ray cells.

\section{Tabebuia aurea (Fig. 1d-f)}

Growth rings: boundaries distinct, demarcated by lines or bands of marginal parenchyma. Vessels: diffuse-porous; solitary and in short (1-3 cells) radial multiples; tangential diameter 64(44-91)14 $\mu \mathrm{m}$; 63(47-79)12 vessels per square millimetre; simple perforation plates; alternate intervessel pits. Axial parenchyma: predominantly confluent, and lozengealiform, in lines (up to 3 cells wide) and in bands (up to 5 cells wide), vasicentric. Rays: 1- or 2-seriate; 12(9-14)2 rays per linear millimetre; all ray cells procumbent. Fibres: very thick-walled; non-septate. Storied structure: rays and vessel elements irregularly storied. Secretory elements: absent. Mineral inclusions: prismatic crystals in ray cells.

\section{Terminalia glabrescens (Fig. 1g-i)}

Growth rings: boundaries distinct, demarcated by thick-walled and radially flattened fibres. Vessels: diffuse-porous; solitary and in short (1-3 cells) radial multiples; tangential diameter 73
(50-109) $16 \mu \mathrm{m} ; 30(22-36) 5$ vessels per square millimetre; simple perforation plates; alternate intervessel pits. Axial parenchyma: predominantly confluent, and lozenge-aliform, vasicentric, unilateral paratracheal. Rays: exclusively 1-seriate; 16(12-18)2 rays per millimetre; all ray cells upright and/or square, and procumbent, square and upright cells mixed throughout the ray. Fibres: thick to very thick-walled; septate. Storied structure: absent. Secretory elements: occasionally intercellular canals of traumatic origin. Mineral inclusions: absent.

\section{Ocotea corymbosa (Fig. 2a-c)}

Growth rings: boundaries indistinct or absent. Vessels: diffuseporous; solitary and in short (1-3 cells, rarely 4 cells) radial multiples; tangential diameter $37(27-46) 4 \mu \mathrm{m} ; 49(38-62) 7$ vessels per square millimetre; simple perforation plates; alternate intervessel pits. Axial parenchyma: scanty paratracheal slightly distinct. Rays: 1-3-seriate; 13(9-16)2 rays per millimetre; body cells procumbent with one row of upright and/or square marginal cells, and procumbent, square and upright cells mixed throughout the ray. Fibres: thick-walled; septate. Storied structure: absent. Secretory elements: oil cells present among fibres, associated with ray and axial parenchyma. Mineral inclusions: prismatic crystals in ray cells.

\section{Pleroma oleifolium (Fig. 2d-f)}

Growth rings: boundaries distinct, demarcated by thick-walled and radially flattened fibres. Vessels: diffuse-porous; solitary and in short (1-3 cells) radial multiples; tangential diameter 46(24-95)15 $\mu \mathrm{m}$; 55(36-70)15 vessels per square millimetre; simple perforation plates; alternate intervessel pits. Axial parenchyma: scanty paratracheal slightly distinct. Rays: 3-5seriate; $12(7-16) 3$ rays per linear millimetre; procumbent, square and upright cells mixed throughout the ray. Fibres: thick-walled; septate. Storied structure: absent. Secretory elements: absent. Mineral inclusions: druses in parenchyma cells.

\section{Myrcia bella (Fig. 2g-i)}

Growth rings: boundaries distinct, demarcated by thick-walled and radially flattened fibres. Vessels: diffuse-porous; exclusively solitary (90\% or more); tangential diameter 56(39-80) $10 \mu \mathrm{m}$; 44(32-60)9 vessels per square millimetre; simple perforation plates; alternate intervessel pits. Axial parenchyma: diffuse and diffuse-in-aggregates. Rays: 1-3-seriate; $17(13-21) 3$ rays per millimetre; body ray cells procumbent with mostly 2-4 rows of upright and/or square marginal cells. Fibres: thin- to thick-walled; non-septate. Storied structure: absent. Secretory elements: absent. Mineral inclusions: prismatic crystals in fibres.

\section{Tocoyena formosa (Figs 3a-c, 4a)}

Growth rings: boundaries distinct, demarcated by thick-walled and radially flattened fibres. Vessels: diffuse-porous; solitary and in short ( $1-3$ cells) and long ( $>4$ cells) radial multiples; tangential diameter $36(25-49) 6 \mu \mathrm{m} ; \sim 100$ vessels per square millimetre; simple perforation plates; alternate intervessel pits. Axial parenchyma: diffuse and diffuse-in-aggregates. Rays: 1-3seriate; 16(13-19)2 rays per millimetre; procumbent, square and upright cells mixed throughout the ray; height $>1 \mathrm{~mm}$. 

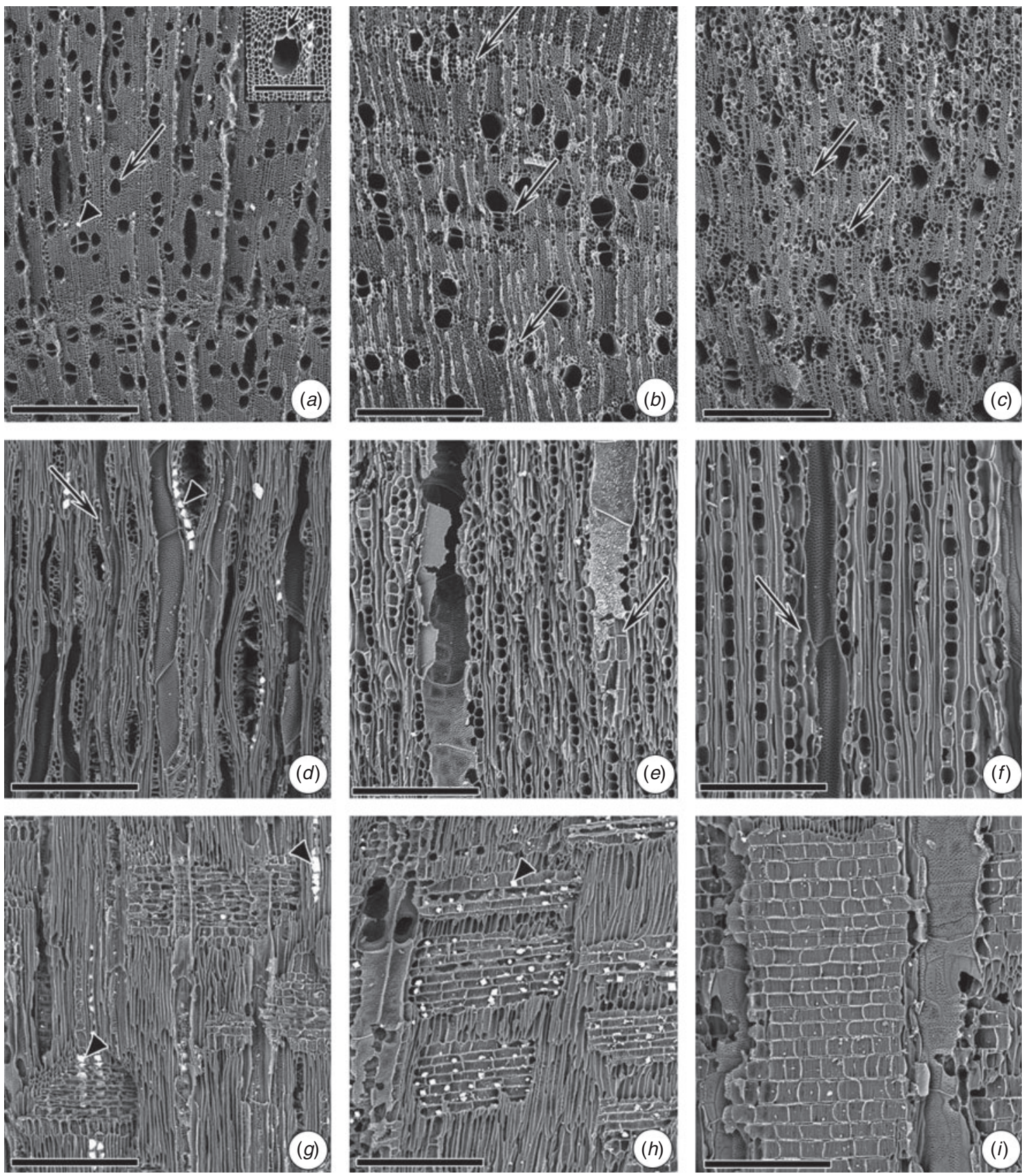

Fig. 1. (a-c) Lithraea molleoides. (a) Transverse section (TS). (b) Tangential longitudinal section (TLS). (c) Radial longitudinal section (RLS). $(d-f)$ Tabebuia aurea. $(d)$ TS. $(e)$ TLS. $(f)$ RLS. $(g-i)$ Terminalia glabrescens. $(g)$ TS. $(h)$ TLS. $(i)$ RLS. Large arrowheads point to individual prismatic crystals $(a, f)$ and to chambered axial parenchyma cells $(b, c)$. Thin arrows point to axial parenchyma, scanty $(a, b)$ and abundant $(d, e, g, h)$. Scale bars: $500 \mu \mathrm{m}$ $(a, d, g) ; 250 \mu \mathrm{m}(b, c, e, f, h, i)$.

Fibres: very thick-walled, non-septate. Storied structure: absent. Secretory elements: absent. Mineral inclusions: crystal sand in axial parenchyma and ray cells.

Siparuna brasiliensis (Figs 3d-f, 4b)

Growth rings: boundaries distinct, demarcated by thick-walled and radially flattened fibres. Vessels: diffuse-porous; solitary and in short ( $1-3$ cells) and long (>4 cells) radial multiples; tangential diameter 44(29-59) $8 \mu \mathrm{m}$; $85(62-103) 15$ vessels per square millimetre; simple and multiple perforation plates with $<10$ bars; alternate intervessel pits. Axial parenchyma: diffusein-aggregates and in lines up to 3 cells wide. Rays: 1-3-seriate; 11(6-13)2 rays per millimetre; all cells upright and/or square; and with procumbent, square and upright cells mixed throughout the ray; height $>1 \mathrm{~mm}$. Fibres: thin- to thick-walled; non-septate. Storied structure: absent. Secretory elements: absent. Mineral inclusions: prismatic crystals in ray cells. 

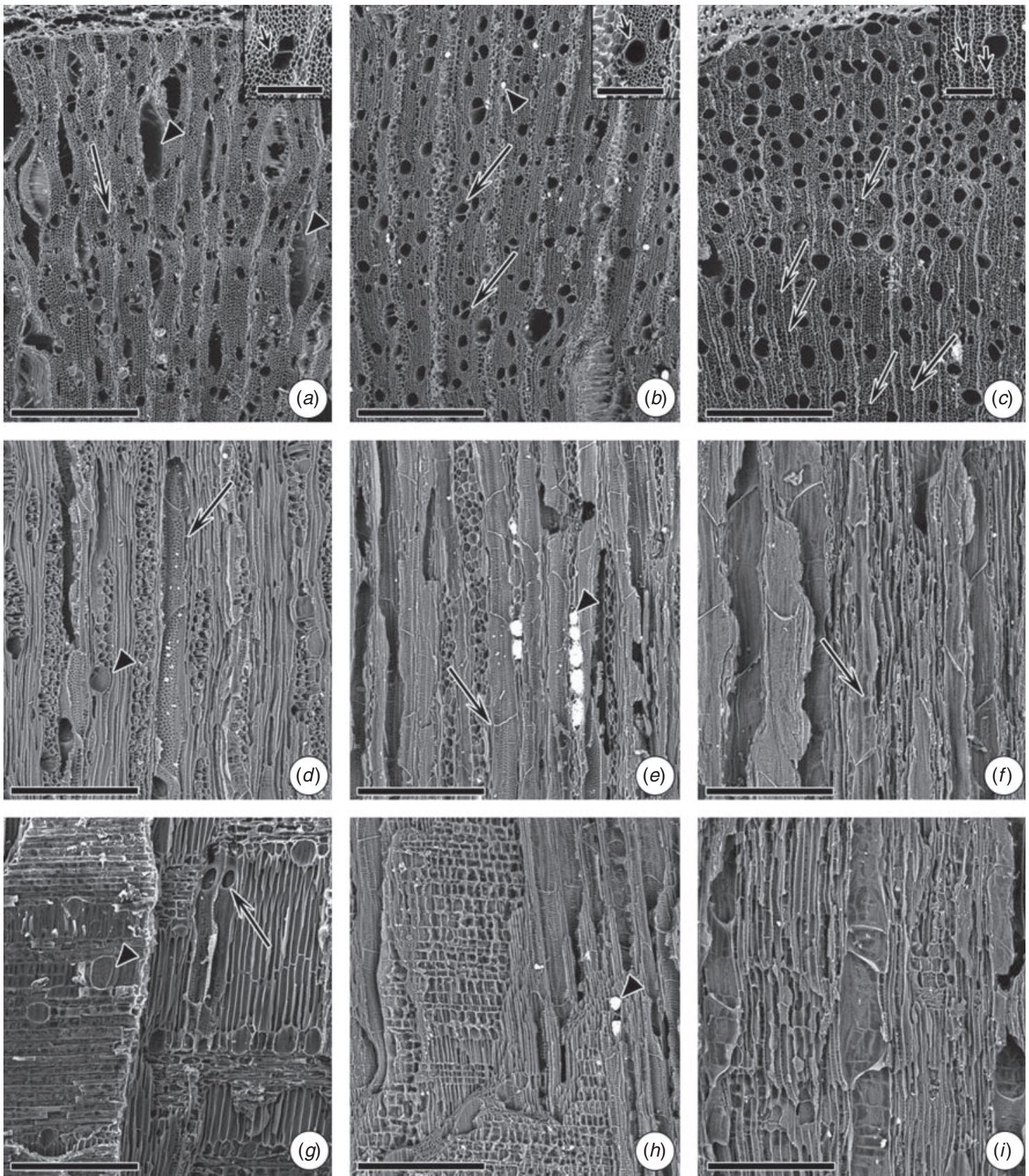

Fig. 2. ( $a-c)$ Ocotea corymbosa. (a) Transverse section (TS); large arrowheads point ruptures; thin arrows point to scanty parenchyma in low and high magnifications. (b) Tangential longitudinal section (TLS); large arrowhead points an oil cell, thin arrow points to scanty parenchyma. (c) Radial longitudinal section (RLS); large arrowhead points to an oil cell, thin arrow points to a simple perforation plate. (d-f) Pleroma oleifolium. (d) TS. (e) TLS. ( $f$ ) RLS. Large arrowheads point to druses $(d, e, f)$, thin arrows point to scanty parenchyma in low and high magnifications $(d, e)$. $(g-i)$ Myrcia bella. $(g)$ TS. $(h)$ TLS. $(i)$ RLS. Thin arrows point to diffuse and diffuse-in-aggregates parenchyma $(g, h)$, in detail diffuse parenchyma $(g)$. Scale bars: $500 \mu \mathrm{m}(a, d, g) ; 250 \mu \mathrm{m}(b, c, e, f, h, i)$.

\section{Styrax ferrugineus (Figs 3g-i, 4c)}

Growth rings: boundaries distinct, demarcated by thick-walled and radially flattened fibres. Vessels: diffuse-porous; solitary and in short (1-3 cells) and long (>4 cells) radial multiples; tangential diameter $67(48-92) 10 \mu \mathrm{m} ; 56(45-66) 6$ vessels per square millimetre; scalariform perforation plates with $<10-20$ bars; alternate intervessel pits. Axial parenchyma: diffuse and diffuse-in-aggregates. Rays: 1-4-seriate; 8(6-10)1 rays per linear millimetre; body cells procumbent with over 4 rows of upright and/or square marginal cells; height $>1 \mathrm{~mm}$. Fibres: thin- to thick-walled; non-septate. Storied structure: absent. Secretory elements: absent. Mineral inclusions: absent. 

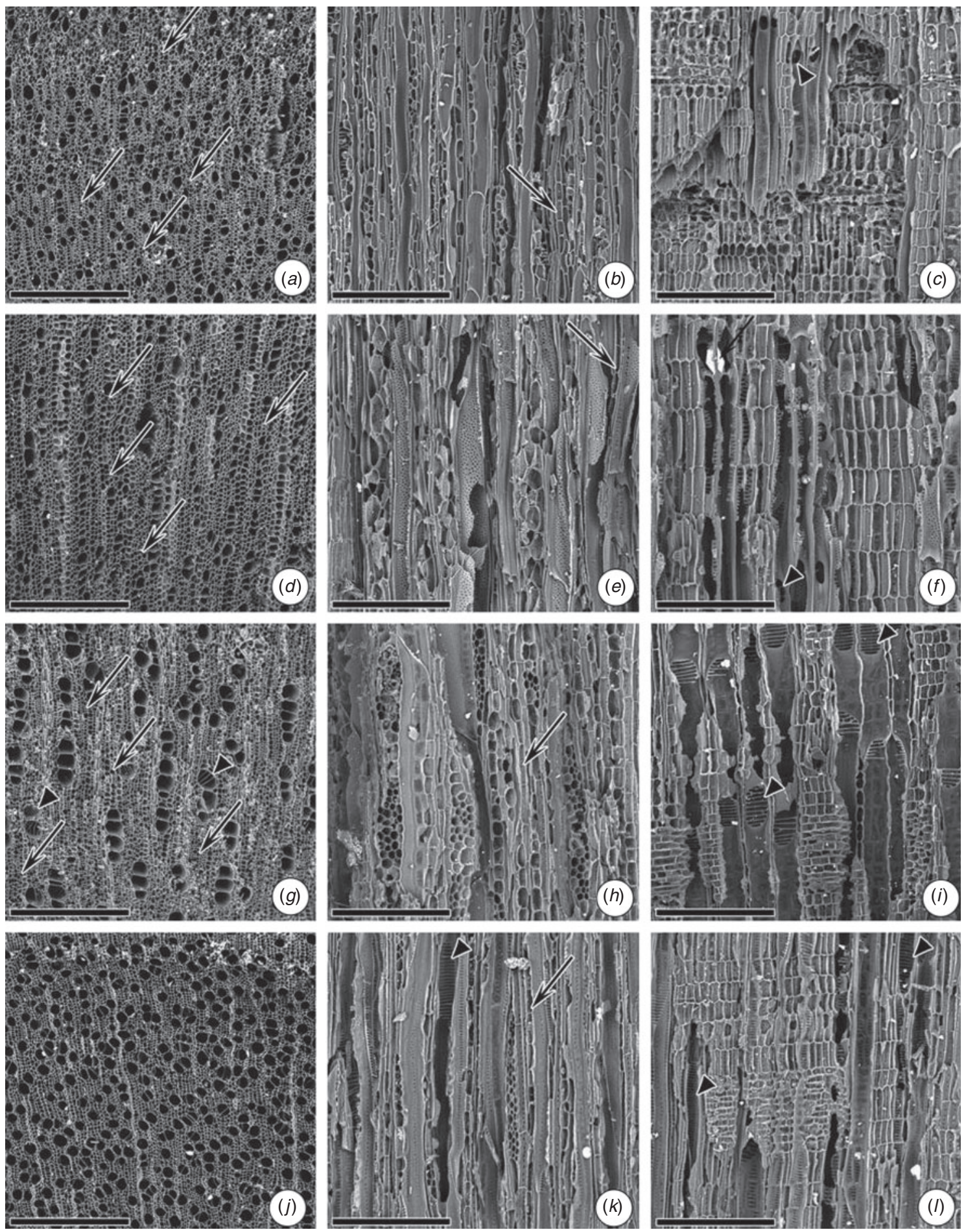

Fig. 3. ( $a-c)$ Tocoyena formosa. (a) Transverse section (TS). (b) Tangential longitudinal section (TLS). (c) Radial longitudinal section (RLS). Thin arrows point to diffuse and diffuse-in-aggregates parenchyma $(a, b)$; large arrowhead points to a simple perforation plate. $(d-f)$ Siparuna brasiliensis. $(d)$ TS. (e) TLS. $(f)$ RLS. Thin arrows point to diffuse and diffuse-in-aggregates parenchyma $(d, e)$; thin, large black arrow points to a prismatic crystal $(f)$. $(g-i)$ Styrax ferrugineus. $(g)$ TS. $(h)$ TLS. ( $i)$ RLS. Thin arrows point to diffuse and diffuse-in-aggregates parenchyma $(g, h)$; large arrowheads point to vessels with scalariform perforation plates with $<10-20$ bars $(g, i)$. $(j-l)$. Symplocos pubescens. ( $j)$ TS. ( $k$ ) TLS. (l) RLS. The thin arrow points to axial parenchyma $(k)$; large arrowheads point to vessels with scalariform perforation plates with 20 to $>40$ bars $(i)$. Scale bars: $500 \mu \mathrm{m}(a, d, g, j) ; 250 \mu \mathrm{m}$ (b, $c, e, f, h, i, k, l)$. 

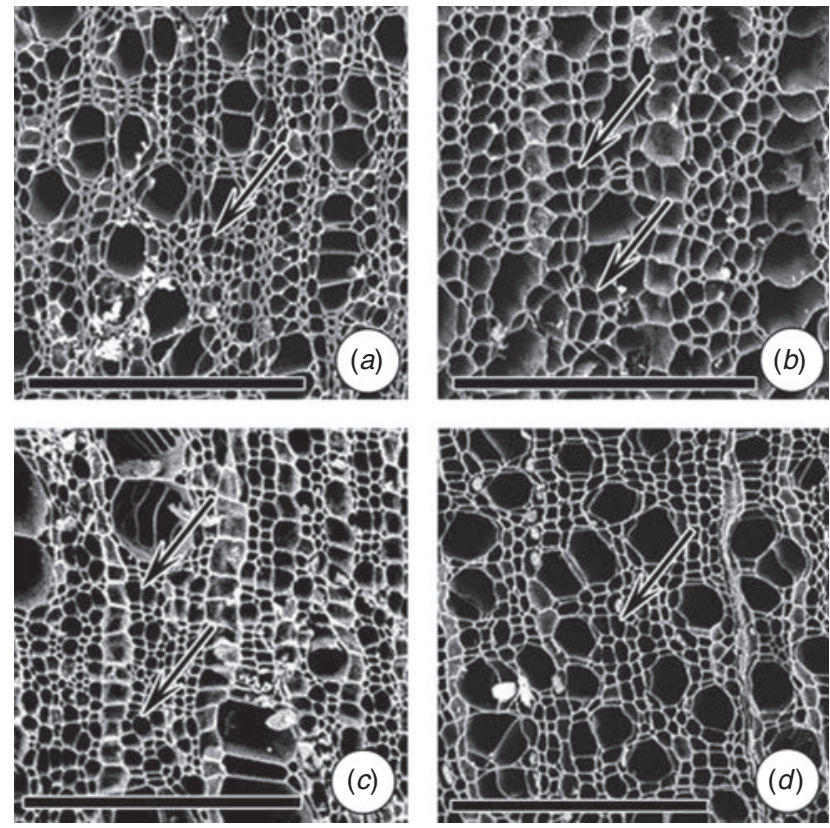

Fig. 4. High magnifications of transverse sections. (a) Tocoyena formosa. (b) Siparuna brasiliensis. (c) Styrax ferrugineus. (d) Symplocos pubescens. Thin arrows point to the diffuse-in-aggregates parenchyma. Scale bars: $125 \mu \mathrm{m}$.

\section{Symplocos pubescens (Figs 3j-I, 4d)}

Growth rings: boundaries distinct, demarcated by thick-walled and radially flattened fibres. Vessels: diffuse-porous; solitary (70\%) and multiples (30\%); tangential diameter 49(38-60)5 $\mu \mathrm{m}$; $>100$ vessels per square millimetre; scalariform perforation plates with 20 to $>40$ bars; alternate intervessel pits. Axial parenchyma: diffuse and diffuse-in-aggregates. Rays: 1-3seriate; 7(4-9)2 rays per millimetre; body cells procumbent with over 4 rows of upright and/or square marginal cells. Fibres: thin- to thick-walled; non-septate. Storied structure: absent. Secretory elements: absent. Mineral inclusions: absent.

\section{Identification key}

1a. Axial parenchyma paratracheal or absent or rare ..................................

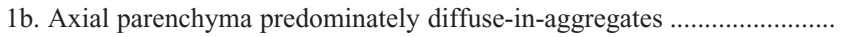

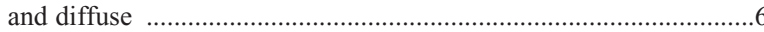

2a. Axial parenchyma scanty and/or absent or rare ..................................... 3

2b. Other types of axial parenchyma paratracheal .....................................

3a. Oil cells present; rays 1-3-seriate

Ocotea corymbosa (Fig. $2 a-c$ )

$3 b$. Oil cells absent; rays $3-5$ seriate; druses in parenchyma cells

Pleroma oleifolium (Fig. 2d-f)

4a. Axial parenchyma scanty and vasicentric; small to medium vessels (35-67 $\mu \mathrm{m})$, medium to a high density $\left(55-81\right.$ vessels $\left.\mathrm{mm}^{-2}\right)$; prismatic crystals in chambered axial parenchyma cells

Lithraea molleoides (Fig. 1a-c)

4b. Axial parenchyma predominately short and long confluent ..................5

5a. Rays and vessel elements irregularly storied; small to medium vessels (44-91 $\mu \mathrm{m})$; high density (47-79 vessels $\mathrm{mm}^{-2}$ ); rays 1- or 2-seriate, all ray cells procumbent

Tabebuia aurea (Fig. 1d-f)

5 b. Storied structure absent; medium to large vessels $(50-109 \mu \mathrm{m})$, medium density (22-36 vessels $\mathrm{mm}^{-2}$ ); rays exclusively 1 -seriate, all ray cells mixture or upright and/or square; might present intercellular canals of traumatic origin

Terminalia glabrescens (Fig. 1g-i)

6a. Vessels exclusively solitary, medium to large vessels $(39-80 \mu \mathrm{m})$, medium to a high density (32-60 vessels $\mathrm{mm}^{-2}$ ); rays 1-3-seriate, body ray cells procumbent with mostly $2-4$ rows of upright and/or square marginal cells

Myrcia bella (Fig. 2g-i)

6b. Vessels solitary and in radial multiples ... ........................................7

7a. Simple perforation plates, small vessels $(25-49 \mu \mathrm{m})$, very high density $\left(\sim 100\right.$ vessels $\left.\mathrm{mm}^{-2}\right)$; rays $1-3$-seriate, procumbent, square and upright cells mixed throughout the ray, ray height $>1 \mathrm{~mm}$

Tocoyena formosa (Figs $3 a-c, 4 a$ )

7b. Multiple perforation plates

8a. Scalariform perforation plates with 20 to $>40$ bars; small to medium vessels $(38-60 \mu \mathrm{m})$, very high density $\left(>100\right.$ vessels $\left.\mathrm{mm}^{-2}\right)$

Symplocos pubescens (Figs $3 j-l, 4 d$ )

8b. Vessels exclusively in radial multiples

9a. Scalariform perforation plates with fewer than 10 bars, small to medium vessels $(29-59 \mu \mathrm{m})$, high to very high density $\left(62-103\right.$ vessels $\left.\mathrm{mm}^{-2}\right)$; ray height $>1 \mathrm{~mm}$

Siparuna brasiliensis (Figs $3 g-i, 4 b$ )

9b. Scalariform perforation plates with fewer than 10 to 20 bars, medium vessels $(48-92 \mu \mathrm{m})$, high density (45-66 vessels $\mathrm{mm}^{-2}$ ); ray height $>1 \mathrm{~mm}$

Styrax ferrugineus (Figs $3 j-l, 4 c$ )

\section{Discussion}

Most of the qualitative anatomical features in charcoal of the 10 studied species were similar to their original wood (see Sonsin et al. 2014); however, considering the focus of the present work, we did not compare the quantitative features. We are aware of the practical difficulties associated with the agents' work, such as the absence of reference materials and constant training. In this regard, SEM images can facilitate the identification of the anatomical structure of the charcoal even in the macroscopic analysis with portable magnifying glasses.

Some features are more difficult to observe in charcoal than in wood, such as, especially, axial parenchyma, which is (1) paratracheal scanty in Lithraea molleoides, Ocotea corymbosa and Pleroma oleifolium, and (2) apotracheal diffuse and diffuse-in-aggregates in Myrcia bella, Tocoyena formosa, Siparuna brasiliensis, Styrax ferrugineus and Symplocos pubescens. However, despite this difficulty, it was possible to identify these features under microscopic observation, but not under portable magnifying glasses with $\times 25, \times 65$ and $\times 100$ magnifications (Gonçalves et al. 2016).

Other features were easily identified, for example, (1) vessel porosity and arrangement in all species, (2) abundant axial parenchyma, which is short and long confluent in Tabebuia aurea and Terminalia glabrescens, (3) ray width and composition in all species, (4) multiple perforation plates in Siparuna brasiliensis, Styrax ferrugineus and Symplocos pubescens, and (5) storied structure in Tabebuia aurea. The presence of mineral inclusions was well distinguished by their format and brightness; the focussed beam of electrons scanning the surface in SEM gives a distinct reflection of light as it would happen under stereomicroscope or reflected light microscopy, for example, prismatic crystals in axial parenchyma cells of Lithraea molleoides and in ray cells of Tabebuia aurea 
and Ocotea corymbosa, and druses in enlarged parenchyma cells of Pleroma oleifolium.

In wood-anatomy analysis, mineral inclusions are usually identified under light microscopy by their format. The druses in Fig. $2 e$ are not as clear as the ones found in IAWA Committee $(1989$, p. 314) because of the nature of charcoal. Also, the reflection of light on the equipment was too high in these mineral inclusions, but the charcoal structure got overly dark when we decreased the light. The presence of druses in the wood of same species were observed by Sonsin et al. (2014).

Oil cells were present only in Ocotea corymbosa and contributed to the species separation in the identification key. Nevertheless, it should be used with caution in this case, because oil cells are usually present in Lauraceae species (e.g. Wheeler 2011).

Ruptures were either present or absent regardless of ray width, which was already mentioned for various species in different climatic conditions (e.g. McGinnes et al. 1971; Kim and Hanna 2006; Braadbaart and Poole 2008; Dias Leme et al. 2010; Théry-Parisot and Henry 2012; Gonçalves et al. 2012, 2014, 2016; Souza et al. 2015; Afonso et al. 2015; Gasson et al. 2017; Osterkamp et al. 2018). It is important to mention that the presence of ruptures might compromise the analysis if the professional is not well trained. Also, the presence of traumatic canals should not be confused with ruptures. They can be distinguished by their format; for example, ruptures are more lozenge to round in longitudinal direction, whereas traumatic canals are relatively rounded to oval in tangential direction when compared to vessels and ruptures (Gonçalves et al. 2012, 2014).

The carbonisation system (equipment, heating rate and time of permanence) and the species anatomy directly influence the presence of ruptures. Depending on the goal of a study, a more suitable carbonisation system may be selected. For example, charcoals in reference collections must preserve their anatomy with a minimal influence of the carbonisation imperfections (e.g. Pearsall 2000; Scheel-Ybert et al. 2006; Gonçalves and ScheelYbert 2016); meanwhile, when simulating real conditions, the carbonisation aims to reflect regular ovens; thus, charcoals might present more ruptures (e.g. Muñiz et al. 2012a, 2012b; Gonçalves et al. 2014, 2016), such as in the present work.

New projects and technologies have been developed because of difficulties in finding specialists on wood anatomy and databases containing wood-anatomy information. One example is a new software based on an artificial vision that could identify wood of 77 African species with almost $90 \%$ accuracy (Affonso et al. 2017; Rosa da Silva et al. 2017). This method could be applied to charcoal, but a huge database would have to be constructed. In addition, a method developed by Florsheim (Thomas 2016) remotely identifies species on the basis of a multitask team and a wood anatomical database. This method could be used for charcoal identification, potentially preventing deforestation in Brazil and could also be applied in other countries in Latin-America, Africa and Asia, with similar problems.

\section{Conclusions}

The present work has provided scientific information about the anatomy of charcoals from Cerrado species. The results contribute to the supervision by government agents because we have provided anatomical descriptions, SEM images and a dichotomous key. Despite the resemblance among the species, it was possible to separate them on the basis of anatomy. The most important features were axial parenchyma type, storied structures, vessel features and oil cells. We are aware of the limited access to SEM by the surveillance agents; nonetheless, our images will facilitate their work, allowing comparison of the images with unidentified charcoals. We emphasise the need for a development of a charcoal database that could be used to prevent illegal charcoal production in Brazil and other countries with similar problems.

\section{Conflicts of interest}

The authors declare no conflicts of interest.

\section{Acknowledgements}

The first author received sponsorship of Programa de Capacitação Institucional (MPEG/MCTIC) of CNPq Brazil (PCI-DB 313161/2016-0) while was developing the present article. Silvana Nisgoski receives production grants from CNPq Brazil (PQ 303374 /2016-0).

\section{References}

Affonso C, Rossi ALD, Vieira FHA, Carvalho ACPLF (2017) Deep learning for biological image classification. Expert Systems with Applications $\mathbf{8 5}$, 114-122. doi:10.1016/j.eswa.2017.05.039

Afonso CMI, Gonçalves TAP, Muniz GIB, Nisgoski S, Matos JLM (2015) Mozambique's charcoals: anatomy of nine native species. Bosque 36, 105-112. doi:10.4067/S0717-92002015000100011

Asouti E (2003) Woodland vegetation and fuel exploitation at the prehistoric campsite of Pinarbasi, south-central Anatolia, Turkey: the evidence from the wood charcoal macro-remains. Journal of Archaeological Science 30, 1185-1201. doi:10.1016/S0305-4403(03)00015-3

Beuchle R, Grecchi RC, Shimabukuro YE, Seliger R, Eva HD, Sano E, Achard F (2015) Land cover changes in the Brazilian Cerrado and Caatinga biomes from 1990 to 2010 based on a systematic remote sensing sampling approach. Applied Geography 58, 116-127. doi:10.1016/j.apgeog.2015.01.017

Braadbaart F, Poole I (2008) Morphological, chemical and physical changes during charcoalification of wood and its relevance to archaeological contexts. Journal of Archaeological Science 35, 2434-2445. doi: 10.1016/j.jas.2008.03.016

Byrne C, Dotte-Sarout E, Winton V (2013) Charcoals as indicators of ancient tree and fuel strategies: an application of anthracology in the Australian midwest. Australian Archaeology 77, 94-106.

Davrieux F, Rousset PLA, Pastore TCM, Macedo LA, Quirino WF (2010) Discrimination of native wood charcoal by infrared spectroscopy. Quimica Nova 33, 1093-1097. doi: $10.1590 /$ S0100-40422010000500016

Dias Leme CL, Cartwright C, Gasson P (2010) Anatomical changes to the wood of Mimosa ophthalmocentra and Mimosa tenuiflora when charred at different temperatures. IAWA Journal 31, 333-351. doi: $10.1163 / 22941932-90000027$

Dotte-Sarout E, Carah X, Byrne C (2015) Not just carbon: assessment and prospects for the application of anthracology in Oceania. Archaeology in Oceania 50, 1-22. doi:10.1002/arco.5041

Figueiral I, Mosbrugger V (2000) A review of charcoal analysis as a tool for assessing Quaternary and Tertiary environments: achievements and limits. Palaeogeography, Palaeoclimatology, Palaeoecology 164, 397-407. doi:10.1016/S0031-0182(00)00195-4

Ganem RS (2013) 'Legislação brasileira sobre meio ambiente.' (Câmara dos Deputados: Brasília, Brazil) 
Gasson P, Cartwright C, Dias Leme CL (2017) Anatomical changes to the wood of Croton sonderianus (Euphorbiaceae) when charred at different temperatures. IAWA Journal 38, 117-123. doi:10.1163/22941932-20170161

Gonçalves TAP, Scheel-Ybert R (2012) Contra o carvão ilegal: estudo da anatomia da madeira pode ajudar a salvar florestas nativas. Ciência Hoje 292, 74-76.

Gonçalves TAP, Scheel-Ybert R (2016) Charcoal anatomy of Brazilian species. I. Anacardiaceae. Anais da Academia Brasileira de Ciências 88, 1711-1725. doi:10.1590/0001-3765201620150433

Gonçalves TAP, Rangel A, Scheel-Ybert R (2008) Caracterização anatômica do lenho carbonizado de espécies comuns do cerrado: subsidio a estudos antracológicos e conservacionistas. In 'IX simpósio nacional do Cerrado e II simpósio internacional de savanas tropicais', Brasília, Brazil. Available at www.cpac.embrapa.br/download/567/t [Verified 10 August 2017].

Gonçalves TAP, Marcati CR, Scheel-Ybert R (2011) Wood and charcoal anatomy in species of the Brazilian Cerrado: effect of carbonization on wood structure. SAGUNTUM 11, 51-52.

Gonçalves TAP, Marcati CR, Scheel-Ybert R (2012) The effect of carbonization on wood structure of Dalbergia violacea, Stryphnodendron polyphyllum, Tapirira guianensis, Vochysia tucanorum, and Pouteria torta from the Brazilian cerrado. IAWA Journal 33, 73-90. doi:10.1163/22941932-90000081

Gonçalves TAP, Ballarin AW, Nisgoski S, Muniz GIB (2014) A contribution to the identification of charcoal origin in Brazil I: anatomical characterization of Corymbia and Eucalyptus. Maderas. Ciencia y Tecnología 16, 323-336. doi:10.4067/S0718-221X2014005000025

Gonçalves TAP, Nisgoski S, Oliveira JS, Marcati CR, Ballarin AW, Muniz GIB (2016) A contribution to the identification of charcoal origin in Brazil II: macroscopic characterization of Cerrado species. Anais da Academia Brasileira de Ciências 88, 1045-1054. doi:10.1590/0001-3765201620150322

Heinz C, Thiébault S (1998) Characterization and palaeoecological significance of archaeological charcoal assemblages during late and post-glacial phases in southern France. Quaternary Research 50, 56-68. doi:10.1006/qres.1998.1978

IAWA Committee (1989) List of microscopic features for hardwood identification. IAWA Journal 10, 219-332.

IBGE (Instituto Brasileiro de Geografia e Estatística) (2004) 'Mapa de biomas do Brasil, primeira aproximação.' (IBGE: Rio de Janeiro) Available at www.ibge.gov.br [Verified 10 August 2017].

IBGE (Instituto Brasileiro de Geografia e Estatística) (2012) 'Manual técnico da vegetação Brasileira.' (IBGE: Rio de Janeiro)

Kim N-H, Hanna RB (2006) Morphological characteristics of Quercus variabilis charcoal prepared at different temperatures. Wood Science and Technology 40, 392-401. doi:10.1007/s00226-005-0062-5

Klink CA, Machado RB (2005) Conservation of the Brazilian Cerrado. Conservation Biology 19, 707-713. doi:10.1111/j.1523-1739.2005.00702.x

Marguerie D (1992) 'Evolution de la végétation sous l'impact humain en armorique du néolithique aux périodes historiques.' (Université de Rennes I: Rennes, France)

McGinnes EA Jr, Kandeel SA, Szopa PS (1971) Some structural changes observed in the transformation of wood into charcoal. Wood and Fiber 3, 77-83.

MMA (Ministério do Meio Ambiente) (2011) 'Monitoramento do desmatamento nos biomas brasileiros por satélite - acordo de cooperação técnica MMA/IBAMA: monitoramento do bioma Cerrado 2009-2010.' (MMA: Brasília, Brazil)

Muñiz GIB, Nisgoski S, Shardosin FZ, França RF (2012a) Anatomia do carvão de espécies florestais. Cerne 18, 471-477.

doi:10.1590/S0104-77602012000300015
Muñiz GIB, Nisgoski S, França RF, Schardozin FZ (2012b) Anatomia comparativa da madeira e carvão de Cedrelinga catenaeformis Ducke e Enterolobium schomburgkii Benth. para fins de identificação. Scientia Forestalis 40, 291-297.

Muñiz GIB, França RF, Fiorese AD, Nisgoski S (2013) Análisis de la estructura anatómica de la madera y del carbón de dos especies de Sapotaceae. Maderas. Ciencia y Tecnología 15, 311-320. doi:10.4067/S0718-221X2013005000024

Muñiz GIB, Carneiro ME, Batista FRR, Schardozin FZ, Nisgoski S (2016) Wood and charcoal identification of five species from the miscellaneous group known in Brazil as 'Angelim' by Near-IR and wood anatomy. Maderas. Ciencia y Tecnología 18, 505-522. doi:10.4067/S0718-221X2016005000045

Myers SN, Mittermeier RA, Mittermeier CG, Fonseca GAB, Kent J (2000) Biodiversity hotspots for conservation priorities. Nature 403, 853-858. doi: $10.1038 / 35002501$

Nellemann C, Henriksen R, Raxter P, Ash N, Mrema E (2014) 'The environmental crime crisis: threats to sustainable development from illegal exploitation and trade in wildlife and forest resources.' A UNEP Rapid Response Assessment. (UNEP - United Nations Environment Programme and GRID-Arendal: Nairobi and Arendal). Available at https://www.cbd.int/financial/monterreytradetech/unepillegaltrade.pdf. [Accessed 20 August 2017].

Nisgoski S, Muñiz GIB, França RF, Batista FRR (2012) Anatomia do lenho carbonizado de Copaifera cf. langsdorfii Desf. e Dipteryx odorata (Aubl.) Wild. Ciência da Madeira 3, 66-79. doi:10.12953/2177-6830.v03n02a01

Nisgoski S, Magalhães WLE, Batista FRR, França RF, Muñiz GIB (2014) Anatomical and energy characteristics of charcoal made from five species. Acta Amazonica 44, 367-372. doi:10.1590/1809-4392201304572

Nisgoski S, Muñiz GIB, Morrone SR, Schardosin FZ, França RF (2015) NIR and anatomy of wood and charcoal from Moraceae and Euphorbiaceae species. Ciência da Madeira 6, 183-190. doi:10.12953/2177-6830/rcm.v6n3p183-190

Osterkamp IC, Lara DM, Gonçalves TAP, Kauffmann M, Périco E, Stulp S, Machado NTG, Uhl D, Jasper A (2018) Changes of wood anatomy of selected Araucaria species during artificial charring: implications for palaeontology. Acta Botanica Brasílica 6, 198-211. doi:10.1590/0102-33062017abb0360

Pearsall DM (2000) 'Paleoethnobotany: a handbook of procedures.' (Academic Press: San Diego, CA)

Prior J, Gasson P (1993) Anatomical changes on six African hardwoods. IAWA Journal 14, 77-86. doi:10.1163/22941932-90000579

Prior J, Williams DP (1985) An investigation of climatic change in the Holocene epoch using archaeological charcoal from Swaziland, southern Africa. Journal of Archaeological Science 12, 457-475. doi:10.1016/0305-4403(85)90005-6

Rosa da Silva N, Ridder M, Baetens JM, Bulcke JV, Rousseau M, Bruno OM, Beeckman H, Acker JV, Baets B (2017) Automated classification of wood transverse cross-section micro-imagery from 77 commercial central-African timber species. Annals of Forest Science 74, 30. doi:10.1007/s13595-017-0619-0

Scheel-Ybert R, Gonçalves TAP (2017) 'Primeiro atlas antracológico de espécies brasileiras/ First anthracological atlas of Brazilian species.' (Museu Nacional, Universidade Federal do Rio de Janeiro: Rio de Janeiro). Available at http://www.museunacional.ufrj.br/publicacoes/ wp-content/arquivos/livdigital10.pdf. [Accessed 13 January 2018].

Scheel-Ybert R, Gouveia SEM, Pessenda LCR, Coutinho LM, Boulet R (2003) Holocene palaeoenvironmental evolution of the cerrado and semideciduous forest zone in the São Paulo State (Brazil), based on anthracology and soil d13C analysis. The Holocene 13, 73-81. doi:10.1191/0959683603h1596rp 
Scheel-Ybert R, Carvalho MA, Moura RPO, Gonçalves TAP, Scheel M, Ybert J-P (2006) Coleções de referência e bancos de dados de estruturas vegetais: subsídios para estudos paleoecológicos e paleoetnobotânicos. Arquivos do Museu Nacional. Museu Nacional (Brazil) 64, 255-266.

SFB (Serviço Florestal Brasileiro) (2010) 'Florestas do Brasil em resumo 2010: dados de 2005-2010.' (SFB: Brasília, Brazil)

Sonsin JO, Gasson PE, Machado SR, Caum C, Marcati CR (2014) 'Atlas da diversidade de madeiras do Cerrado Paulista.' (FEPAF: Botucatu, Brazil)

Souza MJC, Silva KS, Perdigão CRV, Silva GR, Melo LEL (2015) Anatomia do lenho carbonizado de espécies madeireiras comercializadas na Amazônia. Boletim Técnico da Fundação Casa da Cultura de Marabá $08,5-13$.

Théry-Parisot I, Henry A (2012) Seasoned or green? Radial cracks analysis as a method for identifying the use of green wood as fuel in archaeological charcoal. Journal of Archaeological Science 39, 381-388.

doi:10.1016/j.jas.2011.09.024
Théry-Parisot I, Chabal L, Chrzavzez J (2010) Anthracology and taphonomy, from wood gathering to charcoal analysis: a review of the taphonomic processes modifying charcoal assemblages, in archaeological contexts. Palaeogeography, Palaeoclimatology, Palaeoecology 291, 142-153. doi:10.1016/j.palaeo.2009.09.016

Thomas JA (2016) 'O CSI das árvores.' (Veja, Ed. Abril: São Paulo, Brazil) Available at http://veja.abril.com.br/ciencia/o-csi-das-arvores/ [Accessed 20 August 2017].

Vernet J-L (1972) Nouvelle contribution à l'histoire de la végétation holocène des Grands Causses d'après les charbons de bois. Bulletin de la Société Botanique de France 119, 169-182. doi:10.1080/00378941.1972.10839134

Wheeler EA (2011) InsideWood: a web resource for hardwood anatomy. IAWA Journal 32, 199-211. doi:10.1163/22941932-90000051

Handling editor: Anthony O'Grady 